\title{
Commentary on "Thoracic aortic endografting facilitates the resection of tumors infiltrating the aorta"
}

\author{
Marc R. Moon, MD
}

See related article by Collaud et al in the April 2014 issue (J Thorac Cardiovasc Surg. 2014;147:1178-82).

Collaud and associates ${ }^{1}$ from Toronto have described their experience with prophylactic stent-graft placement followed by wide resection for lung cancer invading the thoracic aorta. ${ }^{1}$ This clinical scenario is rare, only 5 patients in 5 years at one of the larger thoracic surgical centers in the world, but it can present a formidable surgical challenge even in the most experienced of hands. The classic approach for tumors that invade the mid descending aorta is to gain proximal and distal control; if penetration deep to the adventitial layer is encountered, partial or complete circumferential resection is performed. Patch repair with bovine pericardium, placement of a short Dacron polyester fabric graft or end-to-end reanastomosis restores aortic integrity. A clamp and sew approach is possible, but I prefer a brief period of extracorporeal bypass to maintain distal perfusion. There is a theoretic concern that the addition of cardiopulmonary bypass might increase risk, potentially related to inflammatory changes and fluid shifts with increased bleeding consequent to heparinization. In my experience, however, most of these tumor resections can be performed with partial left heart bypass with venous inflow through the nonresected pulmonary vein or left atrial appendage and arterial return through the distal aorta or femoral artery. Full heparinization is not required with left heart bypass (activated clotting times of 250 seconds are adequate), pump times are short (30 minutes or less), and the priming volume is low with a small circuit, eliminating the hemodilution that typically occurs with full cardiopulmonary bypass. Of course, this approach necessitates the inclusion of a thoracic aortic surgeon as part of the operative team, but when this is properly performed, the patient "hardly notices" that the aorta has been clamped. Remember, as Dr Norman Shumway used to say, "The pump is your friend."2

Collaud and associates ${ }^{1}$ did not include any historical controls, so it is difficult to assess the claim of a diminution in operative risk. Spaggiari and associates ${ }^{3}$ reported

From the Washington University School of Medicine, St Louis, Mo.

Disclosures: Author has nothing to disclose with regard to commercial support.

Received for publication Jan 16, 2014; accepted for publication Feb 3, 2014; available ahead of print March 4, 2014

Address for reprints: Marc R. Moon, MD, Department of Cardiothoracic Surgery,

3108 Queeny Tower, One Barnes Hospital Plaza, St. Louis, MO 63110-1013,

United States (E-mail: moonm@wustl.edu).

J Thorac Cardiovasc Surg 2014;147:1456-7

$0022-5223 / \$ 36.00$

Copyright (c) 2014 by The American Association for Thoracic Surgery

http://dx.doi.org/10.1016/j.jtcvs.2014.02.016 extended resection in 125 patients, including 14 with aortic involvement. This 2013 series and an older 2008 series from Europe reported $0 \%$ mortality, with major morbidity rates of $7 \%$ to $23 \%$. ${ }^{3,4}$ Prophylactic stent-graft placement followed by aortic resection without the pump, as described Collaud and associates, ${ }^{1}$ is not without theoretic risks. These include an additional surgical procedure, coverage of a more extensive length of aortic lumen (4-cm landing zone on each end of the resection margin), and a small but real lifelong risk of erosion or infection with a stent-graft in an otherwise normal segment of aorta. Furthermore, I have nightmares at the thought of an exposed endograft in an infected field, a problem that may be less likely if primary reanastomosis or a bovine patch reconstruction had been performed. That being said, there are two clinical scenarios in which I feel that the Toronto approach offers a potential advantage. First, this technique appears quite beneficial when aortic arch involvement is present. The principles of proximal and distal control are difficult to follow with invasion of the arch, and fenestrated stent-grafts, as recently described by Nagata and associates, ${ }^{5}$ offer a potential powerful tool to treat these patients. Second, for tumors that invade the spine, the endograft will exclude intercostals in the region of resection to potentially decrease intraoperative bleeding during resection of the involved vertebrae.

Technically speaking, Collaud and associates ${ }^{1}$ note that in patient 5 the aortic defect was reconstructed over the stent-graft with bovine pericardium to prevent the stentgraft from protruding and bleeding at each end. I strongly encourage them to repair the aortic defect with bovine pericardium always, even if the defect is small, to exclude the prosthetic graft from the pleural space and decrease the risk of aortopulmonary or aortoesophageal fistulization. I would not be content with a simple pleural or intercostal muscle flap coverage in most of these cases.

In summary, the Toronto group has developed a technique that works well in their hands and is likely reproducible by those experienced in endovascular techniques and complex thoracic surgery. This is an approach that tertiary centers can now add to their surgical armamentarium. I feel strongly however, that this should not be considered the standard of care and that inexperienced surgeons should not consider this a low-risk approach that allows them to attack a very complex surgical problem with which they would otherwise not be comfortable.

\footnotetext{
References

1. Collaud S, Waddell TK, Yasufuku K, Oreopoulos G, Rampersaud R, Rubin B, et al. Thoracic aortic endografting facilitates the resection of tumors infiltrating the aorta. J Thorac Cardiovasc Surg. 2014;147:1178-82.
} 
2. Fann JI, Baumgartner WA. Historical perspectives of the American Association for Thoracic Surgery: Norman E. Shumway, Jr (1923-2006). J Thorac Cardiovasc Surg. 2011;142:1299-302.

3. Spaggiari L, Tessitore A, Casiraghi M, Guarize J, Solli P, Borri A, et al. Survival after extended resection for mediastinal advanced lung cancer: lessons learned on 167 consecutive cases. Ann Thorac Surg. 2013;95:1717-25.
4. Wex P, Graeter T, Zaraca F, Haas V, Decker S, Bugdayev H, et al. Surgical resection and survival of patients with unsuspected single node positive lung cancer (NSCLC) invading the descending aorta. Thorac Surg Sci. 2009;6:Doc02.

5. Nagata T, Nakamura Y, Yamamoto H, Sato M. A fenestrated stent graft for surgical resection of lung cancer invading the aortic arch. J Thorac Cardiovasc Surg. 2013; $146: 238-9$.

Access to The Journal of Thoracic and Cardiovascular Surgery Online is reserved for print subscribers!

Full-text access to The Journal of Thoracic and Cardiovascular Surgery Online is available for all print subscribers. To activate your individual online subscription, please visit The Journal of Thoracic and Cardiovascular Surgery Online, point your browser to http://www.mosby.com/jtcvs, follow the prompts to activate your online access, and follow the instructions. To activate your account, you will need your subscriber account number, which you can find on your mailing label (note: the number of digits in your subscriber account number varies from 6 to 10 ). See the example below in which the subscriber account number has been circled:

\section{Sample mailing label}

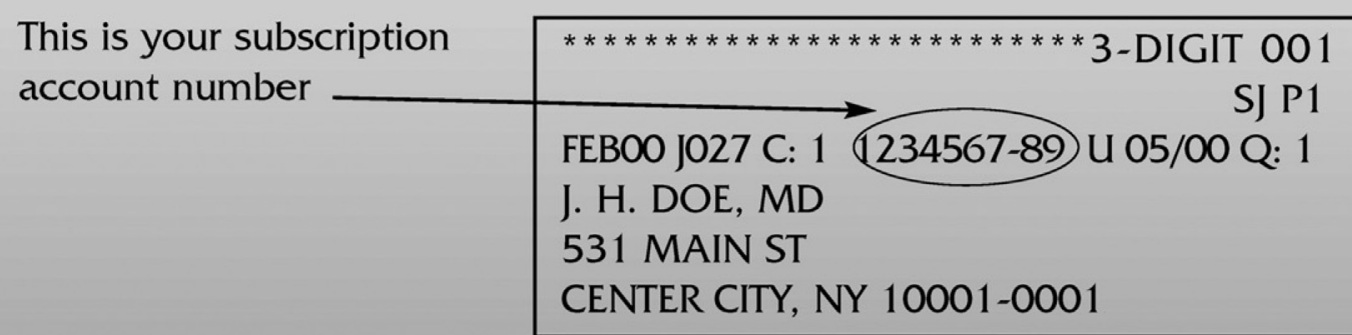

Personal subscriptions to The Journal of Thoracic and Cardiovascular Surgery Online are for individual use only and may not be transferred. Use of The Journal of Thoracic and Cardiovascular Surgery Online is subject to agreement to the terms and conditions as indicated online. 